\title{
Interference of Pteridium arachnoideum (Kaulf.) Maxon. (Dennstaedtiaceae) on the establishment of rainforest trees
}

\author{
Silva Matos, DM.* and Belinato, TA. \\ Departamento de Botânica, Universidade Federal de São Carlos — UFSCar, \\ CP 676, CEP 13565-905, São Carlos, SP, Brazil \\ *e-mail: dmatos@ufscar.br
}

Received Frebuary 12, 2009 - Accepted May 26, 2009 - Distributed May 31, 2010

(With 1 figure)

\begin{abstract}
In order to identify the effect of $P$. arachnoideum, we studied 11 native tree species commonly used in reforestation projects. Bioassays were conducted in laboratory to evaluate the effect of bracken leachate on the germination and morphology of seedlings. Juveniles of some of these species were planted in two adjacent but contrasting areas in relation to the dominance of $P$. arachnoideum. The evaluation of growth and survivorship was performed after six and twelve months. This study reveals that for some pioneer and secondary trees $P$. arachnoideum leachate exerted an inhibitory effect on seed germination and seedling morphology. Field experiments revealed that pioneers are apparently more resistant to $P$. arachnoideum leachate than secondary species.
\end{abstract}

Keywords: invasive species, Pteridium arachnoideum, tropical trees, bracken, germination, seedlings.

\section{Interferência de Pteridium arachnoideum (Kaulf.) Maxon. (Dennstaedtiaceae) no estabelecimento de árvores tropicais}

\section{Resumo}

Na tentativa de identificar o efeito de $P$. arachnoideum, estudamos 11 espécies nativas comumente utilizadas em projetos de reflorestamento. Bioensaios foram conduzidos em laboratório para avaliar o efeito do extrato aquoso do samambaião sobre a germinação e morfologia de plântulas. Plantas jovens de algumas destas espécies foram plantadas em duas áreas adjacentes, porém contrastantes em relação à dominância de $P$. arachnoideum. A avaliação do crescimento e sobrevivência foi realizada após seis e doze meses. Este estudo revela que, para algumas espécies pioneiras e secundárias tropicais, $P$. arachnoideum exerce um efeito inibidor sobre a germinação de sementes e a morfologia de plântulas. Experimentos de campo mostram que as espécies pioneiras são aparentemente mais resistentes ao $P$. arachnoideum do que as espécies secundárias.

Palavras-chave: espécies invasoras, Pteridium arachnoideum, árvores tropicais, samambaião, germinação, plântulas.

\section{Introduction}

The Atlantic Rain Forest of southeast Brazil is one of the most diverse ecosystems in the world (Myers et al., 2000 ) but has been reduced to $8 \%$ of its original area (SOS Mata Atlântica and INPE, 1993). Over centuries its large and continuous areas have been destroyed as a consequence of urban and agricultural expansion (Siqueira et al., 2004), leaving remaining forest fragments isolated and scattered through a matrix of grasses and bracken (Pteridium arachnoideum (Kaulf.) Maxon. (Dennstaedtiaceae), hereafter referred to as Pteridium). Much of this change has been brought about by burning with an average of 75-fire occurrences/year counted in one Atlantic Forest urban reserve, where the primary fuels include invasive grasses and ferns (Silva Matos et al., 2002). The first species invading after fire are often Panicum maximum followed by Pteridium (Silva Matos et al., 2005). Where this occurs the fire keeps the vegetation in a state dominated by such invasive species, which then start to encroach into forest areas.

Pteridium spp. is a weed widely distributed throughout the world (Page, 1976), and its harmful attributes are well known (Watt, 1940; Alonso-Amelot and Rodulfo-Baechler, 1996; Humphrey and Swaine, 1997). Pteridium produces a large frond and rhizome biomass, large accumulations of litter which can compete directly with other species, especially developing seedlings. The underground rhizome structure is fire resistant and contains a large carbohydrate store and a large number of 
frond-producing buds (Watt, 1940; Glass, 1976; Glass and Bohm, 1969; Lowday and Marrs, 1992; Snow and Marrs, 1997; Marrs et al., 1998; Johnson 2001). Pteridium has been described as a typical aggressive inflammable pioneer species, occurring in burnt or deforested sites (Alonso-Amelot and Rodulfo-Baechler, 1996; Humphey and Swaine, 1997; Snow and Marrs, 1997). Moreover, Pteridium produces what may be allelopathic compounds affecting the establishment and growth of other plant species (Gliessman and Muller, 1978; den Ouden, 2000; Gliessman, 1976 apud den Ouden, 2000; Marrs and Watt, 2006).

Most studies on the impact of bracken on plant communities have been carried out in the temperate zone of the northern hemisphere, and almost nothing is known about the ecology of bracken in the sub-tropics and tropics (Gliessman, 1976 apud den Ouden, 2000; Silva Matos et al., 2005; Silva and Silva Matos, 2006). Here we report the results of an experiment designed to test the hypothesis that Pteridium interfered with tree colonisation. We investigated the effects of Pteridium on the germination and establishment of native tree species from the Atlantic Forest in Brazil. This was done at two stages; first we assessed whether there was any effect from chemicals leached from the Pteridium fronds on seed germination, and second we compared tree seedling performance in an intact bracken stand and a stand where the Pteridium fronds were removed about a month earlier.

\section{Material and Methods}

The effects of Pteridium interference on seed germination was tested in the laboratory on 11 tree species, and the impact of Pteridium fronds was tested in the field on six of these species. The tree species (Table 1) occurs in the Atlantic Rain Forest (Lorenzi, 1998) and they have all been used in forest re-forestation projects. The species were classified a priori as either pioneer or non-pioneer species based on the rationale of Swaine and Whitmore (1988), i.e, pioneers are those whose seed can germinate in canopy open gaps and seedlings do not occur under canopy shade; secondary are those species whose seeds can germinate under a forest canopy and their seedlings occur in forest shade. Plant nomenclature followed the Missouri Botanical Garden electronic database while information about the successional stage of each species was obtained from the literature (Lorenzi, 1992; Lorenzi, 1998).

\subsection{Laboratory bioassays of leachates on seed germination}

An aqueous leachate was prepared: $50 \mathrm{~g}$ fresh bracken fronds were ground in $500 \mathrm{~mL}$ of distilled water and filtered (Inderjit and Dakshini, 1995). Twenty five seeds of each of the 11 species were counted into individual Petri dishes fitted with a filter paper. Two treatments were applied: 1) the filter paper was saturated with the leachate, and 2) the filter paper was saturated with the distilled water. A completely randomised experimental design was used with 11 species $\times 2$ treatments $\times 4$ replicates. The dishes were observed twice weekly for four weeks, numbers of germinated seeds were counted (judged by the production of a radicle and hypocotyl), and humidity was measured. The dishes were watered with approximately $5 \mathrm{~mL}$ of distilled water when necessary (Randhawa et al., 2002). The length and diameter of the radicle and hypocotyl, were measured weekly for all seedlings using a digital caliper.

\subsection{Impact of Pteridium fronds in the field}

The field study was carried out in two adjacent areas of dense Pteridium ( 0.5 ha) in the mountain region of Rio de Janeiro State (22 $13^{\circ} 40^{\prime \prime} \mathrm{N}$ and $42^{\circ} 57^{\prime} 40^{\prime \prime} \mathrm{W}$ ). In one area the Pteridium was allowed to grow naturally and in the second area all Pteridium fronds were harvested on a regular basis so that the fronds were not allowed to develop a canopy. Both plots were in a matrix surrounding forest fragments and had no tree canopy cover, and they had a similar soil type, shading, and history.

Within each area 10 plots $(9 \times 9 \mathrm{~m})$ were set up at random positions. The tree saplings were planted in these plots using a planting design that takes into account the successional status of each species (Crestana 1993; Rodrigues and Gandolfi 1988, 1996). The plants were planted in a $3 \times 3$ matrix, with each seedling separated by $3 \mathrm{~m}$. The secondary species (T. heptaphylla or C. odorata) were planted in the central position ( 5 plots each) and two saplings of three of the pioneer species (G. kunthiana, Schinus terebinthifolia, C. superba) were planted randomly in the perimeter positions in each plot.

\subsection{Statistical analysis}

The effects of treatment on 1) seed germination and seedling morphology in the laboratory assays and, 2) sapling growth and survivorship in the field essays were assessed using the Mann-Whitney test (Zar, 1984).

\section{Results}

\subsection{Laboratory bioassays of leachate on seed germination}

The leachate from the Pteridium fronds inhibited the germination of Guazuma ulmifolia, Schinus terebinthifolia, Miconia cinnamomifolia, Tabebuia heptaphylla and Enterolobium contortisiliquum, but stimulated the germination of Cordia superba and Guarea kunthiana (Table 2). The leachate had no significant effect on stem diameter and length, which were not inhibited by the $P$. arachnoideum leachate, and where significance was detected, responses were also conflicting; e.g. leaching increased the stem diameter of Guazuma ulmifolia but reduced that of Cordia superba. For four species (Tibouchina granulosa, Cecropia sp., Miconia cinnamomifolia and Enterolobium contortisiliquum), the leachate stimulated stem length but inhibited root elongation. 
Table 1. Tree species, native to the Atlantic rain forests, used in the laboratory $(\mathrm{L})$ and field $(\mathrm{F})$ experiments.

\begin{tabular}{|c|c|c|c|c|}
\hline Ecological group & Species & Authority & Family & Experiments \\
\hline \multirow[t]{6}{*}{ Pioneer species } & Cecropia sp. & & Cecropiaceae & $\mathrm{L}$ \\
\hline & Cordia superba & Cham. & Boraginaceae & LF \\
\hline & Enterolobium contortisiliquum & (Vell.) Morong & Fabaceae & $\mathrm{L}$ \\
\hline & Guazuma ulmifolia & Lam. & Sterculiaceae & $\mathrm{LF}$ \\
\hline & Schinus terebinthifolia & Raddi & Anacardiaceae & $\mathrm{LF}$ \\
\hline & Tibouchina granulosa & (Desr.) Cogn. & Melastomataceae & $\mathrm{L}$ \\
\hline \multirow[t]{5}{*}{ Secondary species } & Cedrela odorata & L. & Meliaceae & $\mathrm{LF}$ \\
\hline & Chorisia speciosa & A. St.-Hil. & Bombacaceae & $\mathrm{L}$ \\
\hline & Guarea kunthiana & A. Juss & Meliaceae & $\mathrm{L}$ \\
\hline & Miconia cinnamomifolia & (DC.) Naudin & Melastomataceae & $\mathrm{L}$ \\
\hline & Tabebuia heptaphylla & (Vell.) Tol. & Bignoniaceae & LF \\
\hline
\end{tabular}

Table 2. Effects of leachate from Pteridium fronds on the germination, diameter, stem length and root length of tree seedlings compared to the experimental control (water). Mean values \pm sd (italics) are presented; *indicates significant differences $(\mathrm{p}<0.05)$ for Mann-Whitney test.

\begin{tabular}{|c|c|c|c|c|c|c|c|c|}
\hline \multirow[t]{2}{*}{$\begin{array}{l}\text { Plant } \\
\text { species }\end{array}$} & \multicolumn{2}{|c|}{$\begin{array}{c}\text { Germination rate } \\
(\%)\end{array}$} & \multicolumn{2}{|c|}{$\begin{array}{c}\text { Diameter } \\
(\mathrm{mm})\end{array}$} & \multicolumn{2}{|c|}{$\begin{array}{c}\text { Stem length } \\
(\mathrm{mm})\end{array}$} & \multicolumn{2}{|c|}{$\begin{array}{c}\text { Root length } \\
(\mathrm{mm})\end{array}$} \\
\hline & Control & Leachate & Control & Leachate & Control & Leachate & Control & Leachate \\
\hline \multicolumn{9}{|l|}{ Pioneer species } \\
\hline Cecropia sp. & 15 & 15 & $\begin{array}{l}0.51 \\
0.06\end{array}$ & $\begin{array}{l}0.48 \\
0.15\end{array}$ & $\begin{array}{l}4.97 * \\
1.41\end{array}$ & $\begin{array}{l}6.59 * \\
0.97\end{array}$ & $\begin{array}{c}15.54 * \\
5.69\end{array}$ & $\begin{array}{c}11.49 * \\
6.65\end{array}$ \\
\hline Cordia superba & $45^{*}$ & $52 *$ & $\begin{array}{l}1.48 * \\
0.12\end{array}$ & $\begin{array}{l}1.36^{*} \\
0.16\end{array}$ & $\begin{array}{r}31.90 \\
7.87\end{array}$ & $\begin{array}{r}32.02 \\
8.27\end{array}$ & $\begin{array}{l}45.46 \\
17.57\end{array}$ & $\begin{array}{l}41.19 \\
21.12\end{array}$ \\
\hline $\begin{array}{l}\text { Enterolobium } \\
\text { contortisiliquum }\end{array}$ & $33 *$ & $26 *$ & $\begin{array}{l}1.07 \\
0.10\end{array}$ & $\begin{array}{l}1.07 \\
0.10\end{array}$ & $\begin{array}{c}24.29 * \\
6.13\end{array}$ & $\begin{array}{c}27.75^{*} \\
0.04\end{array}$ & $\begin{array}{r}13.95 \\
4.12\end{array}$ & $\begin{array}{r}13.31 \\
5.45\end{array}$ \\
\hline Guazuma ulmifolia & $26^{*}$ & $19 *$ & $\begin{array}{l}0.79 * \\
0.10\end{array}$ & $\begin{array}{l}0.83^{*} \\
0.09\end{array}$ & $\begin{array}{r}18.06 \\
4.75\end{array}$ & $\begin{array}{r}17.73 \\
5.65\end{array}$ & $\begin{array}{c}13.64 * \\
5.08\end{array}$ & $\begin{array}{c}10.67 * \\
4.12\end{array}$ \\
\hline $\begin{array}{l}\text { Schinus } \\
\text { terebinthifolia }\end{array}$ & $20 *$ & $15^{*}$ & $\begin{array}{l}0.62 \\
0.07\end{array}$ & $\begin{array}{l}0.61 \\
0.08\end{array}$ & $\begin{array}{l}22.5 \\
6.10\end{array}$ & $\begin{array}{r}22.17 \\
9.34\end{array}$ & $\begin{array}{c}26.21 * \\
9.68\end{array}$ & $\begin{array}{c}13.87^{*} \\
5.22\end{array}$ \\
\hline $\begin{array}{l}\text { Tibouchina } \\
\text { granulosa } \\
\text { Secondary species }\end{array}$ & 47 & 47 & $\begin{array}{l}0.32 \\
0.09\end{array}$ & $\begin{array}{l}0.33 \\
0.04\end{array}$ & $\begin{array}{l}1.64^{*} \\
0.40\end{array}$ & $\begin{array}{l}1.86^{*} \\
0.75\end{array}$ & $\begin{array}{c}12.71 * \\
7.24\end{array}$ & $\begin{array}{l}1.86^{*} \\
1.39\end{array}$ \\
\hline Cedrela fissilis & $10 *$ & $8^{*}$ & $\begin{array}{l}1.25 \\
0.18\end{array}$ & $\begin{array}{l}1.17 \\
0.18\end{array}$ & $\begin{array}{r}15.86 \\
6.73\end{array}$ & $\begin{array}{r}12.85 \\
8.87\end{array}$ & $\begin{array}{l}4.49 * \\
1.20\end{array}$ & $\begin{array}{l}7.15^{*} \\
2.43\end{array}$ \\
\hline Chorisia speciosa & 74 & 75 & $\begin{array}{l}2.31 \\
0.26\end{array}$ & $\begin{array}{l}2.16 \\
0.40\end{array}$ & $\begin{array}{l}37.20 \\
15.02\end{array}$ & $\begin{array}{l}36.30 \\
12.35\end{array}$ & $\begin{array}{l}34.40 \\
13.74\end{array}$ & $\begin{array}{l}31.91 \\
11.74\end{array}$ \\
\hline Guarea kunthiana & $51 *$ & $64 *$ & $\begin{array}{l}0.86 \\
0.08\end{array}$ & $\begin{array}{l}0.87 \\
0.07\end{array}$ & $\begin{array}{r}11.85 \\
2.39\end{array}$ & $\begin{array}{r}13.05 \\
3.20\end{array}$ & $\begin{array}{c}14.21 * \\
4.62\end{array}$ & $\begin{array}{c}24.86^{*} \\
8.48\end{array}$ \\
\hline $\begin{array}{l}\text { Miconia } \\
\text { cinnamomifolia }\end{array}$ & $47 *$ & $20 *$ & $\begin{array}{l}0.51 \\
0.11\end{array}$ & $\begin{array}{l}0.51 \\
0.11\end{array}$ & $\begin{array}{l}11.48^{*} \\
10.54\end{array}$ & $\begin{array}{c}10.49 * \\
9.73\end{array}$ & $\begin{array}{l}17.71 * \\
11.70\end{array}$ & $\begin{array}{l}7.02 * \\
6.26\end{array}$ \\
\hline $\begin{array}{l}\text { Tabebuia } \\
\text { heptaphylla }\end{array}$ & $20 *$ & $15^{*}$ & $\begin{array}{l}0.69 \\
0.06\end{array}$ & $\begin{array}{l}0.65 \\
0.07\end{array}$ & $\begin{array}{r}10.76 \\
3.44\end{array}$ & $\begin{array}{l}9.06 \\
1.74\end{array}$ & $\begin{array}{r}13.52 \\
4.67\end{array}$ & $\begin{array}{r}10.55 \\
4.27\end{array}$ \\
\hline
\end{tabular}

\subsection{Impact of Pteridium fronds in the field}

After 12 months differential effects on seedling mortality were found; the pioneer species (Schinus terebinthifolia, Cordia superba and Guarea kunthiana) had a greater mortality under Pteridium, but the secondary species (Cedrela fissilis) had a greater mortality in the no-Pteridium area (Figure 1a). No significant differences were found between the growth increments of stem diameter from in either area (Figure 1b). However, both height (Figure 1c) and stem diameter of three pioneer species (Schinus terebinthifolia, Cordia superba and Guarea kunthiana) were slightly greater in the control area whereas the height of the two secondary species (Tabebuia heptaphylla and Cedrela fissilis) was greater in the $P$. arachnoideum stand. 

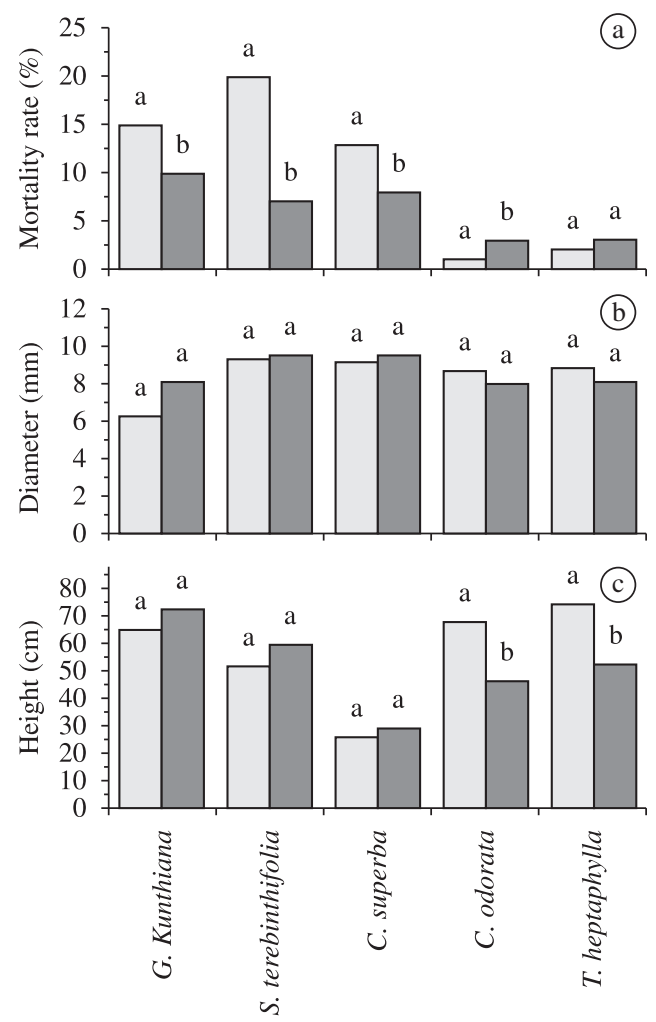

Figure 1. a) Mortality rate, b) growth rate in diameter (cm) and c) growth rate in height $(\mathrm{cm})$ observed for trees within Pteridium arachnoideum (Kaulf.) Maxon. stands (dark gray columns) and control areas (light gray columns).

\section{Discussion}

The interference effect of $P$. arachnoideum on seed germination and seedling growth has been studied extensively (Stewart, 1975; Gliessman and Muller, 1978; Nava et al., 1987; Dolling and Nilsson, 1994; Dolling, 1996). These studies argued that $P$. aquilinum leachate reduces and delays germination and decreases the seedling growth for a number of species. However, several aspects of the allelopathic interference of bracken have been raised for debate (see den Ouden, 2000): the seasonal, ontogenetic and spatial variation of secondary organic compound production, differences of toxicity amongst bracken varieties and the extraction time used in laboratory experiments. In this study we attempt to keep all these aspects under control in order to avoid misinterpretation.

We found out that for some tropical tree species commonly used for the recovery of degraded areas $P$. arachnoideum leachate exerted an inhibitory effect on seed germination. As high and rapid seed germination, along with vigorous seedling growth, are factors that affect the fitness of plants (Gross and Smith, 1991;
Hutchings, 1997; Seiwa, 2000), any inhibitory impact on these processes could decrease the chances of plant establishment. In general, early germinating seedlings have a greater competitive ability because, amongst other factors, they occupy the available space quickly, and pre-empt any resource limitation (Stanton, 1984; Zhang and Maun, 1990; Seiwa, 2000), while later-germinating seedlings can suffer increased mortality and/or reduced growth (Zimmerman and Weis, 1983).

Whereas Marrs et al. (2000) argue that bracken is a mid-successional plant in the plagio-climax in woodlands, heaths, moors and grasslands in Europe, there are situations where bracken can develop into almost a climax community (Marrs et al., 2006). For woodland to develop in such a community it requires some form of disturbance leading $P$. aquilinum to diminish (Marrs and Watt, 2006). In Brazil, we suggest that succession does not take its natural course in the Atlantic Forest without an appropriate management of bracken, for example. Consequently, new insights into the response of species to Pteridium are necessary to understand the role of bracken in succession within tropical ecosystems.

It has been evidenced that the dense understorey layer formed by bracken also increases their impact on succession by decreasing the amount of seeds reaching the soil surface and by increasing shading (Pakeman and Marrs, 1992; Marrs and Watt, 2006). This is also supported by the work of Royo and Carson (2006), who argued that the dense understorey layer in forests is one of the causes of impact on the floristic composition rather than some allelopathic effect. The work of Silva Matos et al. (2005) and Silva and Silva Matos (2006), showed that the occurrence of wild fires and the consequent expansion of grasses and ferns within Atlantic Forest areas is hindering the establishment of secondary vegetation typically found along the natural successional process. Our results contribute to understanding the reasons of such dominance of bracken within this ecosystem and its influence on the establishment of pioneer and secondary tree species. Nevertheless, we assume that compounds produced by $P$. arachnoideum may be one of the factors affecting the natural secondary succession in disturbed areas of Atlantic Rain Forest where bracken occurs.

In conclusion, reforestation projects should take into account the response of tree species to $P$. arachnoideum, especially in the early phases of plant life cycle. Considering that tree canopy can suppress bracken (Marrs et al., 2000), the choice of tree species should also be based on the growth rate and the area occupied by the canopy, as a strategy of stopping its expansion or even reducing its dominance. Additionally, such species can be expected to work as new seed sources that will disperse seeds beyond the impacted area. In the face of response variability of tree species, studies concerning bracken effects have to be carried out, both in the laboratory and in the field, in order to test its role on native tree species rather than using exotic and/or annual plant species only. 
Acknowledgements - The first author thanks the Rio de Janeiro Government for the financial support from FAPERJ. The authors thank FAPERJ for financial support and Marcus Rossari, Felipe César Barros da Rosa, Ana Carolina dos Santos Valente and Renato Aragão for their help in the field work. We are also very grateful to Prof. Dr. Robert H. Marrs and to the anonymous reviewers for their stimulating comments that improved this paper.

\section{References}

ALONSO-AMELOT, ME. and RODULFO-BAECHLER, S., 1996. Comparative spatial distribution, size, biomass and growth rate of two varieties of bracken fern (Pteridium aquilinum L.Kuhn) in a neotropical montane habitat. Vegetatio, vol. 125 , no. 2 , p. 137-147.

CRESTANA, MSM., 1993. Sistema de recuperação com essências nativas. São Paulo: CATI.

DEN-OUDEN, D., 2000. The role of bracken (Pteridium aquilinum) in forest dynamics. Neetherlands: Wageningen University. [PhD Thesis]

DOLLING, A. and NILSSON, M., 1994. Seasonal variation in phytotoxicity of bracken (Pteridium aquilinum L. Kuhn). Journal of Chemical Ecology, vol. 20, no. 12, p. 163-3172.

DOLLING, AHU., 1996. Interference of bracken (Pteridium aquilinum L. Kuhn) with Scots pine (Pinus sylvestris L.) and Norway spruce (Picea abies L. Karst.) seedling establishment. Forest Ecology and Management, vol. 88, no. 3, p. 227-235.

Fundação SOS Mata Atlântica and Instituto Nacional de Pesquisas Espaciais, 2002. Atlas dos Remanescentes Florestais da Mata Atlântica no Período de 1995-2000. São Paulo.

GLASS, ADM., 1976. The allelopathic potential of phenolic acids associated with the rhizosphere of Pteridium aquilinum. Canadian Journal of Botany, vol. 54, no. 21, p. 2440-2444.

GLASS, ADM. and BOHM, BA., 1969.The accumulation of cinnamic and benzoic acid derivatives in Pteridium aquilinum and Athyrium felix-femina. Phytochemistry, vol. 8, no. 2, p. 371-377.

GLIESSMAN, SR. and MULLER, CH., 1978. The allelopathic mechanisms of dominance in bracken (Pteridium aquilinum) in southern California. Journal of Chemical Ecology, vol. 4, no. 3, p. 337-362.

GHORBANI, J., LE-DUC, MG., MCALLISTER, HA., PAKEMAN, RJ. and MARRS, RH., 2006. Effects of the litter layer of Pteridium aquilinum on seed banks under experimental restoration. Applied Vegetation Science, vol. 9, no. 1 , p. 127-136.

GROSS, KL. and SMITH, AD., 1991. Seed mass and emergence time effects on performance of Panicum dichotomiflorum Michx. Across environments. Oecologia, vol. 87, no. 2, p. 270-278.

HUMPHREY, JW. and SWAINE, MP.,1997. Factors affecting the natural regeneration of Quercus in Scottish oakwoods. I Competition from Pteridium aquilinum. Journal of Applied Ecology, vol. 34, no. 3, p. 577-584.

HUTCHINGS, MJ., 1997. The structure of plant populations. In CRAWLEY, MJ. (Ed.). Plant Ecology. Oxford: Blackwell. p. 97-136.
INDERJIT, CA. and DAKSHINI, KMM., 1995. On laboratory bioassays in allelopathy. The Botanical Review, vol. 61, no. 1, p. $28-44$.

JOHNSON, PN., 2001. Vegetation recovery after fire on a southern New Zealand peatland. New Zealand Journal of Botany, vol. 39, no. 2, p. 251-267.

LORENZI, H., 1992. Árvores brasileiras: manual de identificação e cultivo de plantas arbóreas nativas do Brasil. Nova Odessa: Plantarum.

LORENZI, H., 1998. Árvores brasileiras: manual de identificação e cultivo de plantas arbóreas nativas do Brasil. Nova Odessa: Plantarum.

LOWDAY, JE. and MARRS, RH., 1992. Control of bracken and the restoration of heathland. I. Control of bracken. Journal of Applied Ecology, vol. 29, no. 2, p. 195-203.

MARRS, RH., JOHNSONS, SW. and LE-DUC, MG., 1998. Control of bracken and restoration of heathland. VI. The response of bracken fronds to 18 years of continued bracken control or 6 years of control followed by recovery. Journal of Applied Ecology, vol. 35, no. 4, p. 479-490.

MARRS, RH., LE-DUC, MG., MITCHELL, RJ., GODDARD, D., PATERSON, S. and PAKEMAN, RJ., 2000. The ecology of bracken: its role in succession and implications for control. Annals of Botany, vol. 85, no. B, p. 3-15.

MARRS, RH. and WATT, AS., 2006. Biological Flora of the British Isles: Pteridium aquilinum (L.) Kuhn. Journal of Ecology, vol. 94, no. 6, p. 1272-1321.

MYERS, N., MITTERMEIER, RA., MITTERMEIER, CG., FONSECA, GA. and KENT, J., 2000. Biodiversity hotspots for conservation priorities. Nature, vol. 403, no. 6772, p. 853-858.

NAVA, RV., FERNANDEZ, LE. and DEL-AMO, RS., 1987. Allelopathic effects of green fronds of Pteridium aquilinum on cultivated plants, weeds, phytopathogenic fungi and bacteria. Agriculture Ecosystems and Environment, vol. 18, no. 4, p. 357-380.

PAKEMAN, RJ. and MARRS, RH., 1992. The conservation value of bracken Pteridium aquilinum (L.) Kuhn-dominated communities in the UK, and an assessment of the ecological impact of bracken expansion or its removal. Biological Conservation, vol. 62, no. 2, p. 101-114.

RANDHAWA, MA., CHEEMA, ZA. and ALI, MA., 2002. Allelopathic effect of sorghum water extract on the germination and seedling growth of Trianthema portulacastrum. International Journal of Agriculture and Biology, vol. 4, no. 3, p. 383-384.

RODRIGUES, RR. and GANDOLFI, S., 1996. Recomposição de Florestas Nativas: Princípios Gerais e Subsídios para uma Definição Metodológica. Revista Brasileira de Horticultura Ornamental, vol. 2, no. 1, p. 4-15.

RODRIGUES, RR. and GANDOLFI, S., 1988. Restauração de Florestas tropicais: subsídios para uma definição metodológica e indicadores de avaliação e monitoramento. In DIAS, LE. and MELLO, JWV. (Eds.). Recuperação de áreas degradadas. Viçosa: UFV. p. 203-215.

SEIWA, K., 2000. Effects of seed size and emergence time on tree seedling establishment: importance of developmental contraints. Oecologia, vol. 123, no. 2, p. 208-215. 
SILVA, USR. and SILVA MATOS, DM., 2006. The invasion of Pteridium aquilinum and the impoverishment of the seed bank in fire prone areas of Brazilian Atlantic Forest. Biodiversity and Conservation, vol. 15, no. 9, p. 3035-3043.

SILVA MATOS, DM., FONSECA, GDFM. and SILVA-LIMA, L., 2005. Differences on post-fire regeneration of the pioneers Cecropia glazioui and Trema micrantha in a lowland Brazilian Atlantic Forest. Revista de Biologia Tropical, vol. 53, no. 1-2, p. $53,1-4$.

SILVA MATOS, DM., SANTOS, CJ. and CHEVALIER, DR., 2002. Fire and restoration of the largest urban forest of the world in Rio de Janeiro City, Brazil. Urban Ecosystems, vol. 6, no. 3 , p. 151-161.

SIQUEIRA, LP., MATOS, MB., SILVA MATOS, DM., PORTELA, RCQ., BRAZ, MIG. and SILVA-LIMA, L., 2004. Using the variances of microclimate variables to determine edge effects in small forest fragments of Atlantic Rain Forest, Southeastern Brazil. Ecotropica, vol. 10, no. 1, p. 59-64.

SNOW, CSR. and MARRS, RH., 1997. Restoration of Calluna heathland on a bracken Pteridium-infested site in North West England. Biological Conservation, vol. 81, no. 1-2, p. 35-42.
STANTON, ML., 1984. Development and genetic sources of seed weight variation in Raphanus raphanistrum L. (Brassicaceae). American Journal of Botany, vol. 71, no. 8, p. 1090-1098.

STEWART, RE., 1975. Allelopathic potential of western bracken. Journal of Chemical Ecology, vol. 1, no. 2, p. 161-169.

SWAINE, MD. and WHITMORE, TC., 1988. On the definition of ecological species groups in tropical rain forests. Vegetatio, vol. 75 , no. 1-2, p. 81-86.

WATT, AS., 1940. Contributions to the ecology of bracken (Pteridium aquilinum) I. The rhizome. New Phytologist, vol. 39, no. 4, p. 401-411.

ZAR, JH., 1984. Biostatistical analysis. 2 ed. New Jersey: Prentice Hall.

ZHANG, J. and MAUN, MA., 1990. Seed size variation and its effects on seedling growth in Agropyron psammophilum. Botanical Gazzete, vol. 151, no. 1, p. 106-113.

ZIMMERMAN, JK. and WEIS, IM., 1983. Fruit size variation and its effects on germination and seedling growth in Xantium strumarium. Canadian Journal of Botany, vol. 61, no. 9, p. 2309-2315. 